EFFECT OF LAND USE AND TOPOGRAPHY ON SOIL PROPERTIES AND AGRONOMIC PRODUCTIVITY ON CALCAREOUS SOILS OF A SEMIARID REGION, IRAN

\author{
H. Asadi ${ }^{1, *}$, A. Raeisvandi ${ }^{1}$, B. Rabiei ${ }^{1}$, H. Ghadiri ${ }^{2}$ \\ ${ }^{1}$ Faculty of Agricultural Sciences, University of Guilan, Rasht, P.O. Box 41635-1314, Iran. \\ ${ }^{2}$ Faculty of Environmental Sciences, Environmental Future Centre, Griffith University, Nathan, \\ Queensland 4111, Australia. \\ *Corresponding author: Soil Science Department, Faculty of Agricultural Sciences, University of Guilan, \\ Rasht, P.O. Box 41635-1314, Iran. Tel: +98 131 6690388, Fax: +98 131 6690281, Email: \\ asadi@guilan.ac.ir
}




\title{
EFFECT OF LAND USE AND TOPOGRAPHY ON SOIL PROPERTIES AND AGRONOMIC PRODUCTIVITY ON CALCAREOUS SOILS OF A SEMIARID REGION, IRAN
}

\begin{abstract}
In this research the effects of land use and slope position on soil properties and its agronomic productivity were studied in a greenhouse experiment. The study also covered the effects of water stress, fertilizer treatment and their interactions. Eight soil samples were collected from four slope positions along hillslopes from two adjacent land use types of rangeland and dry farmland in a semi arid region of Iran. Soil samples were analyzed for their physical and chemical properties and yield and yield components of wheat were measured as indices of soil agronomic productivity in a replicated pot experiment. Soils of the dry farmland showed higher fertility and better quality than the soils from the adjacent degraded rangeland, especially at the upper slope positions. The results indicated that yield components of wheat were all higher in the dry farming land compare to the degraded rangeland, and in the bottom of slopes compared to the top. The effect of land use and slope position on agronomic productivity of soil was influenced by water supply. The actual impact on soil productivity of soil degradation, induced by land use and slope position, was overshadowed by the dominating effect of water stress. While both chemical fertilizer and fertilizer+manure treatments enhanced the agronomic productivity of all soils, their effects were much more pronounced on the degraded soils of the rangeland. Water stress reduced fertilizer efficiency on all the soils used in this study.

KEY WORDS: dry farming; rangeland; slope position; fertilizer; water stress
\end{abstract}




\section{INTRODUCTION}

The sustainable use of soils is essential for overcoming global issues of $21^{\text {st }}$ century like food security, energy and water shortage, climate change and biodiversity (Lal, 2009; Jones et al., 2009). Soil erosion has been recognized as a major form of soil degradation which adversely affects soil quality by reducing infiltration rates, waterholding capacities, nutrients, organic matter, soil biota and soil depth (Pimentel et al., 1995). Soil erosion also causes a reduction of soil productivity (Verity and Anderson, 1990) and a significant ecological damage by depleting soil biodiversity and affecting plant composition (Lal and Fierce, 1991). Global climate change is expected to exacerbate these problems through changes in atmospheric conditions and land-use.

Soil translocation by tillage and water erosion induces changes in the physical and chemical properties of the soil, including changes in soil texture, organic matter content, chemical composition, nutrient concentrations, and bulk density (Kosmas et al., 2001; de Alba et al., 2004). Removal of soil from up slopes can result in the exposure of subsoil material at shoulder positions and soil deposition patterns may result in a deep $A$ horizon in depressions (Kosmas et al., 2001) or a buried $A$ horizon under some conditions (de Alba et al., 2004).

The spatial variability in quality and quantity of crop yields is often related to the spatial variability in soil quality indicators. In some cases, the spatial variation in soil properties affecting plant growth has been directly linked to changes induced by soil translocation through tillage (Kosmas et al., 2001). Within-field variability in parameters including soil depth, available soil water, nutrients, $\mathrm{pH}$, organic matter content, and indicators of clay content (electrical conductivity and cation exchange capacity) have been reported to affect yield (Kosmas et al., 2001) and crop quality 
(Stewart et al., 2002). Many studies have indicated that grain yields are depressed in areas of a field susceptible to low soil moisture, especially those with coarse soil texture and low organic matter contents. Yields tend to be lowest in eroded areas where calcareous subsoil is exposed and highest in concave positions, which have relatively deep topsoil, especially in dry years (Stewart et al., 2002).

Differences in soil forming factors and processes along a hillslope result in significant differences in soil properties (Brubaker et al., 1993) and plant production (Jones et al., 1989). Soil properties and vegetation can also be altered over time under different land uses, management systems and soil erosion along a hillslope. In rangelands, grazing and more particularly overgrazing and its attendant effect of depletion of plant cover and litter and trampling of the soil is the most important factor contributing to erosion (Branson et al., 1981).

Rangelands, generally located on steep slopes of semi-arid zones, are prone to sever soil erosion. Continued overgrazing or uncontrolled grazing always reduces plant cover that protects the soil and generally results in soil erosion and compaction. Soil erosion, which is a serious problem in many countries, is $20-30$ times more than the tolerance in Iran (Jalalian et al., 1996).

The demand for a standardized methodology for assessing and collecting information on the productivity function of soils has been emphasized by Mueller et al. (2010). This study was aimed to evaluate changes in productivity and soil properties along a landscape on a coupled degraded range land and a dry farming land in a calcareous soil. Yield and yield components of wheat were determined as soil productivity indices as influenced by fertilizer application and water stress. 


\section{MATERIALS AND METHODS}

\section{Soil Sampling and Analysis}

Soil samples were taken from a topographically complex landscape $\left(33^{\circ} 30^{\prime} 12^{\prime \prime} \mathrm{N}\right.$, $47^{\circ} 12^{\prime} 18^{\prime \prime} \mathrm{E}$, altitude: $1100 \mathrm{~m}$ ) in Lorestan province, Iran (Figure 1a), with mean annual temperature of $15.8^{\circ} \mathrm{C}$, mean annual precipitation of $376 \mathrm{~mm}$, and potential evapotranspiration of $1835 \mathrm{~mm}$. Samples (four pairs) from 0-20 $\mathrm{cm}$ depth were randomly collected from up, middle upward, middle downward and foot slope of the hillslope (Figure 1b). The average slope steepness was 17, 26, 20 and 10 percent for the slope positions from up to down, respectively. Each pair of the samples consists of one sample from dry farming field and the other from adjacent rangeland in the same slope position. Soil samples were obtained on early August. The cultivation was conventional up-down tillage by plow tillage (moldboard plow) for about 20 years during that the farmer used to apply annually manure and N-P-K fertilizers. On the other hand, the adjacent permanent rangeland was a degraded rangeland (vegetation cover less than $20 \%$ ) due to intense grazing and dry climate condition.

Based on four slope positions and two land uses (dry farming and range), eight composite soil samples were collected for the greenhouse experiment. Each composite sample weighted about $100 \mathrm{~kg}$ and taken from a $2 \times 4 \mathrm{~m}$ rectangular. Also eight (disturbed and undisturbed by cylinder) soil samples with two replications were randomly collected for the chemical and physical analysis. The chemical and physical analysis carried out on air dried $<2 \mathrm{~mm}$ samples. Measured properties were, soil texture, $\mathrm{pH}$, electrical conductivity (EC), total nitrogen $(\mathrm{N})$, available phosphorous $(\mathrm{P})$ and potassium $(\mathrm{K})$, organic matter content $(\mathrm{OM})$, field capacity moisture (FC), calcium carbonate equivalent (CCE), cation exchange capacity (CEC), bulk density (Bd) and 
mean weight diameter (MWD) of soil aggregates. The soil properties were determined by methods described by Klute (1986) and Sparks (1996).

\section{Greenhouse Evaluation of Soil Productivity}

A factorial experiment based on completely randomized design with three replications was used in the greenhouse experiment to compare the effect of four factors on yield and yield component of wheat. The factors were land use (dry farming and range lands), slope position (up, middle upward, middle downward and foot slope), water stress (with and without water stress) and fertilizer (non-fertilization, chemical fertilization and chemical fertilization+manure). Urea (130 kg ha $\left.{ }^{-1}\right)$, super phosphate triple $\left(150 \mathrm{~kg} \mathrm{ha}^{-1}\right)$ and potassium sulfate $\left(250 \mathrm{~kg} \mathrm{ha}^{-1}\right)$ were used in the chemical fertilization pots. Sheep manure (equivalent to 20 ton $\left.\mathrm{ha}^{-1}\right)$, Urea $\left(60 \mathrm{~kg} \mathrm{ha}^{-1}\right)$, super phosphate triple $\left(125 \mathrm{~kg} \mathrm{ha}^{-1}\right)$ and sulfate potassium $\left(20 \mathrm{~kg} \mathrm{ha}^{-1}\right)$ were used in the chemical+manure fertilization pots. Urea was splitted and used in three stages. Water stress applied from the beginning of earing (end of shooting stage) to the end of growth period by doubling the length of time between two consecutive irrigations as compared to no water stress treatment in which irrigation was done in the depletion limit of $50 \pm 5$ percent of available water content by weighing the pots. Plants in the pots with limited irrigation showed signs of water stress.

A spring wheat (Triticum aestivum L. cv. Atrak) planted with the density of four plants per pot. At the end of growth period, dry matter, grain yield, grain number and grain weight were determined. The obtained data were analyzed by glm procedure of SAS (Statistical Analysis System, 1996) software and Tukey's test was used to compare the mean values. 


\section{RESULTS AND DISCUSSION}

\section{Soil Properties}

Table I summarizes some of the general properties of the soil samples used in this study. Soil texture varied from clay loam (CL) to silt loam (SiL), but the variations were random with no significant difference between treatments. The same was true for texture related properties such as $\mathrm{Bd}, \mathrm{FC}$ and $\mathrm{pH}$. However, land use, slope position, and the interaction between the two had significant effects $(P \leq 0.01)$ on total $\mathrm{N}$, available $\mathrm{P}$ and $\mathrm{K}, \mathrm{OM}$, gravel (particles $>2 \mathrm{~mm}$ ) content, Calcium Carbonate Equivalent (CCE), and CEC. Mean weight diameter (MWD) of soil aggregates was significantly $(P \leq 0.01)$ affected by slope position but not by land use type.

The interactive effect of land use and slope position on soil properties are summarized in Figure 2. The soil OM was generally higher in the dry farming land than the adjacent rangeland, with the differences being higher in the upper parts of the slope than in the footslope. The middle slope section of the landscape on both land use types, where the slope steepness was at its highest, had the lowest level of OM of the three locations (Figure 2). These differences may be due to (i) soil and OM translocation through tillage and erosion from upper to lower part of the slope, (ii) the annual application of manure in the dry farmland, and (iii) over-grazing of the rangeland. Total $\mathrm{N}$ also showed similar variation with land use type and slope position. While there was no significant difference between two land use types in the footslope, total $\mathrm{N}$ was significantly lower in the rangeland than the dry farming land on the upper slopes (Figure 2). This similarity in the pattern of change in $\mathrm{N}$ and $\mathrm{OM}$ is expected as total $\mathrm{N}$ is mostly consists of organic N. Similar results have been reported by other researchers 
(e.g. Raiesi, 2007; Hajabasi and Falahzadeh, 2009) for central Iran, where most rangelands are severely overgrazed and degraded.

Available $\mathrm{K}$ and $\mathrm{P}$ showed a similar trend between treatments (Figure 2). While there was a significant difference between farmland and degraded rangeland at the lower slopes, no significant difference was observed at the upper slopes. These results show that dryland farming on steep slopes reduces soil quality and increases soil degradation, even under good agricultural practices such as fertilizer and manure application. Available soil P was shown by Hajabassi et al. (2002) to be higher in the top $10 \mathrm{~cm}$ of dry farmlands than the adjacent degraded rangelands in the semiarid region of Iran.

The effect of slope positions on $\mathrm{P}$ and $\mathrm{K}$ was generally higher in the farmland than in the rangeland, which indicates a possible mass downslope transport of top soil by tillage practices and erosion. Da Silva and Alexandre (2004) and Lobo et al. (2005) also reported higher concentrations of $\mathrm{N}, \mathrm{P}$ and $\mathrm{K}$ at the bottom of slopes due to erosion.

The farmland soils had higher CEC values than the rangeland soils at all slope positions, but the differences were lower at the upper than the bottom slopes (Figure 2). These differences follow that of the clay and OM of the two land use types and slope positions. This is in agreement with the results obtained by Caravaca et al. (1999).

The changes in CCE of the soils from different land use types and slope locations were in reverse order to those properties discussed above (Figure 2f). Because of more than 20 years of tillage and cultivation practices, it was expected that calcium carbonates leaching to be more pronounced in the farmlands and on higher slopes. The higher levels of CCE in the surface soils of upper slopes, therefore, indicates the loss of top soil by erosion and the exposure of calcareous subsoil material (Papiernik et al., 
2005) at the upper slope positions. Mehdizadeh et al. (2010) also found that CCE is higher at the upslope than mid and foot slope.

Figure $2 \mathrm{~g}$ shows that while percent gravel is uniform across the landscape in the rangeland, it is higher at the upper than the lower slopes in the farmland. MWD of soil aggregates also increased from the top to the bottom of slope (Figure $2 \mathrm{~h}$ ) but the difference between the two land use types was insignificant. The expected positive impact of higher OM and clay content of farmland on MWD appears to have been cancelled out or overshadowed by the negative effect of tillage practices (Mc Vay et al., 2006). Soil EC was higher at the footslope than on the other slope positions, which could have been caused by the higher level of nutrients in the soil from this position.

The above results clearly show that land use and soil management practices influence soil erosion and the processes such as oxidation, mineralization, and leaching of nutrients and other soil chemicals (Wang et al., 2001), thus modifying the processes of transport and re-distribution of nutrients, $\mathrm{OM}$ and soil carbonates. The patterns of water and tillage erosion across the landscapes were found to be mainly dependent on topographic features and they were fundamentally different within topographically complex landscapes (Li et al., 2007).

\section{Agronomic Productivity of Soils}

The analysis of variance (Table II) showed that the effect on yield and yield components of wheat of all investigated factors of land use, slope position, water stress and fertilizer, as well as most of their interactions were significant at $P \leq 0.01$ or $P \leq 0.05$ levels. 


\section{Individual effects of treatments}

The results of mean comparison of yield and yield components of wheat for different treatments, shown in Table III, suggest that; (i) all the yield components of wheat were significantly lower in the rangeland than the dry farmland soils, and in the water stress treatment than without, (ii) dry matter, grain yield and grain number were all significantly higher on the lower slope than on the upper slopes, but reverse was the case for grain weight, (iii) chemical fertilization and chemical+manure fertilization significantly increased wheat yield and yield components, and (iv) the effect of chemical+manure was significantly higher for dry mater and grain number than the effect of chemical fertilizer.

The higher yield in farmland soils compared to the rangeland appears to be directly related to the soil fertility status. As shown in Figure 2, most measured fertility indicators including macronutrients, $\mathrm{OM}, \mathrm{CEC}$ and $\mathrm{CCE}$ were better in the dry farmland than in the rangeland soils. The same is the case for the effects of landscape position on wheat yield, as it was higher at the lower slopes where soil fertility was higher (Figure 2). Soils taken from the midupward slope position in our study yielded the lowest wheat dry matter and grain yield compared with the soils taken from other slope positions. This slope position had the steepest slope gradient, and higher erosion rate thus showing the lowest soil fertility (Figure 2).

\section{Interactive effect of treatments}

There was an interactive effect between land use type and slope position on grain yield and grain weight (Table II). Although both were higher in the farmland than the rangeland on all slope positions, the differences between two land use types were higher at the up- and foot-slopes than at the mid-slope (Figure 3). 
There was no significant difference among the slope positions under water stress condition, but grain yield at the midupward slope position was lower than the other slope positions under no water stress condition. Grain number was also affected in the same way by slope position $\times$ water stress (Figure 4). These results show that the true impact of soil degradation on soil productivity is overshadowed by drought, which is a common phenomenon in the arid and semiarid regions of Iran as also reported by Mehdizadeh et al. (2010).

Results indicate that water stress decreases dry matter, grain yield and grain number more in the farmland than in the rangeland soils (Figure 5), which suggest that the differences between wheat yield on both landscape types is higher when there is adequate water supply, although this water stress effect is insignificant for grain number. Water stress could partially overshadow the influence of other factors such as nutrients, CEC and OM on crop yield, which where shown before to be significantly higher in the farmland than the rangeland soils (Figure 2) and resulted in significantly higher wheat yields (Table III).

The interactions between land use and fertilizer application shows that fertilizers increase wheat growth and yield more efficiently in the degraded soils of rangeland than in the farmland (Figure 6). While the dry matter in the rangeland soils was about 32 percent lower than in the farmland soils under no fertilizer treatment, this difference was reduced to $13 \%$ and zero respectively for fertilizer and fertilizer+manure treatments (Figure 6). Similar results were obtained for the interactive effect of land usexfertilization for grain number (Figure 6). These results show the importance of organic matter (manure) in improving soil quality and increasing the productivity of the degraded soils. 
For the grain yield, there was no significant difference between chemical fertilization and chemical+manure fertilization (Figure 6). Fertilization increased grain yield by 19 and 95 percent in the farmland and rangeland soils, respectively.

Figure 7 shows that fertilizer and fertilizer+manure increased dry matter and grain weight more at the upper slopes than on the lower slopes. The soils taken from upper slopes had lower fertility (Figure 2) than those taken from lower slopes and consequently responded to fertilizer application more efficiently. Similar results were observed when comparing the responses of degraded soils of rangeland and farmland soils to fertilizer as shown in Figure 6.

The mean comparison of the water stress $\times$ fertilization interaction for yield components (Figure 8) clearly showed that water stress significantly reduces fertilizer efficiency for all yield components of wheat. Other researchers have also found that fertilizer efficiency is severely affected by water availability or water stress (Salvagiotti et al., 2009; Mehdizadeh et al., 2010).

\section{CONCLUSION}

All the indicators of soil health and productivity where higher in the soil samples taken from the dry farmland than those taken from the adjacent degraded rangeland. Soil and crop management practices such as manure application and crop husbandry carried out on the farmland, couples with the severe overgrazing of the rangeland appear to be responsible for the observed differences between the two soil management types. Also the soils from footslopes were of better quality and productivity due to higher OM and nutrient contents, higher CEC and lower CCE compared with soils from other 
locations on the slopes. Accumulation of transported $\mathrm{OM}$ and fine particles from upslopes by erosion can improve the quality of soils in the footslopes.

Yield components of wheat were all higher in the dry farming soils as compared with the degraded rangeland soils, and in the soils from lower slopes than from upper slopes. The differences in yield and yield components between the two land use types were generally higher in the soils from the top and foot slopes than from the middle slope. Both nutrient availability and soil properties associated with slope position and land use influence soil agronomic productivity.

The effect of land use type and slope position on agronomic productivity is influenced by water supply. True impact of soil degradation induced by land use and slope position on soil productivity was overshadowed by the dominant effect of water stress. Water stress also reduced the efficiency of chemical fertilizer in increasing yield. While both chemical fertilizer and fertilizer+manure treatments enhanced soil agronomic productivity of soils, their effects were more pronounced on the degraded soils of rangelands than the farmland soils.

\section{RERERENCES}

Branson FA, Gifford GF, Renard KG, Hadley RF. 1981. Evaporation and transpiration. In Rangeland Hydrology, E.H. Reid (Ed.), 2nd Edition. Society of Range Management. Kendull/Hund Publ. Com., Iowa.

Brubaker SC, Jones AJ, Frank K, Lewis DT. 1993. Regression models for estimating soil properties by landscape position. Soil Science Society of America Journal 58: 1763-1767.

Caravaca F, Lax A, Albaladejo J. 1999. Organic matter, nutrient contents and cation exchange capacity in fine fractions from semiarid calcareous soils. Geoderma 93: 161-176.

da Silva JR, Alexandre C. 2004. Soil carbonation processes as evidence of tillage-induced erosion. Soil and Tillage Research 78: 217-224.

de Alba S, Lindstrom M, Schumacher TE, Malo DD. 2004. Soil landscape evolution due to soil redistribution by tillage: A new conceptual model of soil catena evolution in agricultural landscapes. Catena 58(1): 77-100. 
Hajabbasi MA, Falahzadeh J. 2009. Carbohydrates and organic matter distribution in soil aggregates and the effect of land use change. Proceeding of the 11th Iranian Soil Science Congress, 12-15 July 2009, Gorgan University of Agricultural Sciences and Natural Resources, Gorgan, Iran. pp. 1937-1938. (in Persian)

Hajabbasi MA, Jalalian A, Khajedin J, Karimzadeh HR. 2002. Depasturation effects on physical characteristics, fertility and tilth index of soil: A case study of Broojen. Iranian Journal Science Technology of Agricultural Natural Resource 6(1): 149-161. (in Persian with English abstract)

Jalalian A, Ghahsareh AM, Karimzadeh HR. 1996. Soil erosion estimates for some watersheds in Iran. The First International Conference on Land Degradation, 10-14 June, Adana, Turkey, pp. 12-13.

Jones A, Stolbovoy V, Rusco E, Gentile AR, Gardi C, Marechal B, Montanarella L. 2009. Climate change in Europe. 2. Impact on soil. A review. Agronomy for Sustainable Development 29: 423-432.

Jones AJ, Mielke LN, Bartles CA, Miller CA. 1989. Relationship of landscape position and properties to crop production. Journal of Soil and Water Conservation 44: 328-332.

Klute A. 1986. Method of Soil Analysis. Part 1. Physical and Mineralogical Methods. 2nd ed. Agron. Monogr. 9. ASA and SSSA, Madison, WI.

Kosmas C, Gerontidis S, Marathianou M, Detsis B, Zafiriou T, Nan Muysen W, Govers G, Quine T, Van Oost K. 2001. The effects of tillage displaced soil on soil properties and wheat biomass. Soil and Tillage Research 58: 31-44.

Lal R. 2009. Soils and food sufficiency. A review. Agronomy for Sustainable Development 29: $113-133$.

Lal R, Fierce FJ. 1991. The vanishing resource, In Soil Management for Sustainability Lal R, Fierce FJ (Eds.). 189 pp. Soil and Water Conservation Society, Ankeny.

Li S, Lobb DA, Lindstorm MJ, Farenhorst A. 2007. Tillage and water erosion on different landscapes in the northern North American Great Plains evaluated using 137Cs technique and soil erosion models. Catena 70: 493-505.

Lobo D, Lozano Z, Delgado F. 2005. Water erosion risk assessment and impact on productivity of a Venezuelan soil. Catena 64: 297-306.

Mc Vay KA, Budde JA, Fabrizzi K, Mikha MM, Rice CW, Schlegel AJ, Peterson DE, Sweeney DW, Thompson C. 2006. Management effects on soil physical properties in long-term tillage studies in Kansas. Soil Science Society of America Journal 70: 434-438.

Mehdizadeh B, Asadi H, Shabanpour M, Ghadiri H. 2010. The impact of erosion and tillage on the productivity and quality of selected semiarid soils of Iran. Pedosphere (under review).

Mueller L, Schindler U, Mirschel W, Shepherd TG, Ball BC, Helming K, Rogasik J, Eulenstein F, Wiggering H. 2010. Assessing the productivity function of soils. A review. Agronomy for Sustainable Development 30(3): 601-614. DOI: 10.1051/agro/2009057.

Papiernik SK, Lindstrom MJ , Schumacher JA, Farenhorst A, Stephens KD , Schumacher TE, Lobb DA. 2005. Variation in soil properties and crop yield across an eroded prairie landscape. Journal of Soil and Water Conservation 60(6): 388-395.

Pimental DC, Resosudarmo HP, Sinclair K, Kurz D, Mc Nair M, Crist S, Shpritz L, Fitton L, Saffouri R, Blair R. 1995. Environmental and economic costs of soil erosion and conservation benefits. Science 267: 1117-1123. 
Raiesi F. 2007. The conversion of overgrazed pastures to almond orchards and alfalfa cropping systems may favor microbial indicators of soil quality in Central Iran. Agriculture, Ecosystem and Environment 121: 309-318.

Salvagiotti F, Castellarin JM, Miralles DJ, Pedrol HM. 2009. Sulfur fertilization improves nitrogen use efficiency in wheat by increasing nitrogen uptake. Field Crops Research 113: 170177.

Sparks D. 1996. Methods of Soil Analysis, Part III: Chemical Methods. SSSA Book Series NO. 5. Soil Science Society of America, Madison, WI.

Statistical Analysis System. 1996. User's Guide: Statistics. Version 5, SAS Institute Inc. Cary, NY.

Stewart CM, McBratney AB, Skerritt JH. 2002. Sitespecific durum wheat quality and its relationship to soil properties in a single field in Northern New South Wales. Precision Agriculture 3: 155-168.

Verity GE, Anderon DW. 1990. Soil erosion effects on soil quality and yield. Canadian Journal of Soil Science 70: 471-484.

Wang J, Fu B, Qiu Y, Chen L. 2001. Soil nutrients in relation to land use and landscape position in the semi-arid small catchment on the loess plateau in China. Journal of Arid Environment 48 : $537-550$. 
Table I. Some of the general properties of the soil samples

\begin{tabular}{clccccccc}
\hline \multirow{2}{*}{ Land use } & $\begin{array}{c}\text { Slop } \\
\text { position }\end{array}$ & $\begin{array}{c}\text { Clay } \\
(\%)\end{array}$ & $\begin{array}{c}\text { Silt } \\
(\%)\end{array}$ & $\begin{array}{c}\text { Sand } \\
(\%)\end{array}$ & $\begin{array}{c}\text { Soil } \\
\text { Texture }\end{array}$ & $\begin{array}{c}\mathrm{Bd} \\
\left(\mathrm{g} \mathrm{cm}^{-3}\right)\end{array}$ & $\begin{array}{c}\mathrm{FC} \\
(\%)\end{array}$ & $\mathrm{pH}$ \\
\hline \multirow{4}{*}{ Dry farming } & 1 (up) & 28 & 49 & 23 & $\mathrm{CL}$ & 1.29 & 31.1 & 7.4 \\
& 2 & 32 & 50 & 18 & $\mathrm{SiCL}$ & 1.27 & 30.6 & 7.3 \\
& 3 & 31 & 51 & 18 & $\mathrm{SiCL}$ & 1.26 & 31.7 & 7.3 \\
& 4 (down) & 32 & 54 & 14 & $\mathrm{SiCL}$ & 1.22 & 32.6 & 7.3 \\
\multirow{2}{*}{$\begin{array}{c}\text { Degraded } \\
\text { range }\end{array}$} & 2 & 22 & 54 & 24 & $\mathrm{SiL}$ & 1.25 & 30.8 & 7.5 \\
& 3 & 25 & 54 & 21 & $\mathrm{SiCL}$ & 1.23 & 31.0 & 7.4 \\
& 4 (down) & 24 & 52 & 24 & $\mathrm{SiL}$ & 1.22 & 31.5 & 7.4 \\
\hline
\end{tabular}


Table II. Analysis of variance of wheat yield and yield components

\begin{tabular}{|c|c|c|c|c|c|}
\hline \multirow[b]{2}{*}{ S.O.V. } & \multirow[b]{2}{*}{$\mathrm{df}$} & \multicolumn{4}{|c|}{ Mean square } \\
\hline & & $\begin{array}{l}\text { Dry matter } \\
\left(\mathrm{g} \mathrm{plant}^{-1}\right)\end{array}$ & $\begin{array}{l}\text { Grain yield } \\
\left(\mathrm{g} \text { plant }^{-1}\right)\end{array}$ & $\begin{array}{l}\text { Number of grain } \\
\text { (plant }^{-1} \text { ) }\end{array}$ & $\begin{array}{l}\text { Grain weight } \\
\left(\mathrm{g} 1000^{-1}\right)\end{array}$ \\
\hline L.U & 1 & $2.39^{\star \star}$ & $1.84^{\star \star}$ & $431.43^{\star \star}$ & $1447.04^{\star \star}$ \\
\hline S.P & 3 & $0.41^{\star \star}$ & $0.07^{\star \star}$ & $132.58^{\star \star}$ & $164.30^{\star \star}$ \\
\hline W.S & 1 & $27.07^{\star \star}$ & $9.28^{\star \star}$ & $6982.69^{\star \star}$ & $1039.63^{\star \star}$ \\
\hline $\mathrm{F}$ & 2 & $5.80^{\star \star}$ & $0.62^{\star \star}$ & $543.53^{\star \star}$ & $101.98^{\star \star}$ \\
\hline L.U $\times$ S.P & 3 & $0.01^{\mathrm{ns}}$ & $0.04^{\star}$ & $26.70^{\mathrm{ns}}$ & $34.47^{\star}$ \\
\hline L.U $\times$ W.S & 1 & $0.45^{\star \star}$ & $0.50^{\star \star}$ & $193.09^{\star \star}$ & $14.41^{\mathrm{ns}}$ \\
\hline L.U×F & 2 & $0.89^{\star \star}$ & $0.11^{\star \star}$ & $160.16^{\star \star}$ & $19.31^{\mathrm{ns}}$ \\
\hline S.P $\times W . S$ & 3 & $0.05^{\mathrm{ns}}$ & $0.03^{\star}$ & $46.75^{\star}$ & $2.24^{\mathrm{ns}}$ \\
\hline S.P $\times F$ & 6 & $0.17^{\star}$ & $0.02^{\mathrm{ns}}$ & $24.19^{\text {ns }}$ & $33.88^{\star \star}$ \\
\hline $\mathrm{W} . \mathrm{S} \times \mathrm{F}$ & 2 & $0.83^{\star \star}$ & $0.31^{\star \star}$ & $233.53^{\star \star}$ & $3.21^{\mathrm{ns}}$ \\
\hline L.U $\times S . P \times W . S$ & 3 & $0.05^{\mathrm{ns}}$ & $0.02^{\mathrm{ns}}$ & $66.28^{\star \star}$ & $11.88^{\mathrm{ns}}$ \\
\hline L. $U \times S . P \times F$ & 6 & $0.05^{\mathrm{ns}}$ & $0.03^{\star}$ & $35.69^{\star}$ & $13.16^{\mathrm{ns}}$ \\
\hline L.U $\times W . S \times F$ & 2 & $0.05^{\mathrm{ns}}$ & $0.02^{\mathrm{ns}}$ & $21.70^{\mathrm{ns}}$ & $14.52^{\mathrm{ns}}$ \\
\hline $\mathrm{S} . \mathrm{P} \times \mathrm{W} . \mathrm{S} \times \mathrm{F}$ & 6 & $0.07^{\mathrm{ns}}$ & $0.02^{\mathrm{ns}}$ & $23.12^{\text {ns }}$ & $26.48^{\star *}$ \\
\hline L.U $\times S . P \times W . S \times F$ & 6 & $0.03^{\mathrm{ns}}$ & $0.03^{\star}$ & $40.67^{\star \star}$ & $13.03^{\mathrm{ns}}$ \\
\hline E.E & 96 & 0.06 & 0.01 & 13.03 & 8.83 \\
\hline $\mathrm{CV}$ & 143 & 14.22 & 17.05 & 17.18 & 11.13 \\
\hline
\end{tabular}

S.O.V.= sources of variation; $\mathrm{df}=$ degree of freedom; $\mathrm{L} . \mathrm{U}=$ land use; $\mathrm{S} . \mathrm{P}=$ slope position; $\mathrm{W} . \mathrm{S}=$ water stress; $\mathrm{F}=$ fertilizer; $\mathrm{E} . \mathrm{E}=$ experimental error; $\mathrm{CV}=$ coefficient of variation.

Symbols in superscript represent significance of effects: ns, non significant; *, $P \leq 0.05 ; * *, P \leq 0.01$.

Table III. Yield and yield components of wheat as affected by land use, slope position, fertilizer and water stress. 


\begin{tabular}{lcccc}
\hline Treatment & $\begin{array}{c}\text { Dry matter } \\
\left(\mathrm{g} \mathrm{plant}^{-1}\right)\end{array}$ & $\begin{array}{c}\text { Grain yield } \\
\left(\mathrm{g} \mathrm{plant}^{-1}\right)\end{array}$ & $\begin{array}{c}\text { Grain number } \\
\left(\text { plant }^{-1}\right)\end{array}$ & $\begin{array}{c}\text { Grain weight } \\
\left(\mathrm{g} \mathrm{1000^{-1 }}\right)\end{array}$ \\
\hline $\begin{array}{l}\text { Land use } \\
\quad \text { Dry farmland }\end{array}$ & $1.89^{\mathrm{a}}$ & $0.70^{\mathrm{a}}$ & $22.75^{\mathrm{a}}$ & $29.85^{\mathrm{a}}$ \\
$\quad$ Rangeland & $1.63^{\mathrm{b}}$ & $0.47^{\mathrm{b}}$ & $19.28^{\mathrm{b}}$ & $23.51^{\mathrm{b}}$ \\
Slope position & & & & \\
$\quad$ Up slope & $1.73^{\mathrm{b}}$ & $0.60^{\mathrm{a}}$ & $18.90^{\mathrm{b}}$ & $29.78^{\mathrm{a}}$ \\
$\quad$ Midupward slope & $1.62^{\mathrm{ab}}$ & $0.52^{\mathrm{b}}$ & $19.89^{\mathrm{b}}$ & $25.18^{\mathrm{b}}$ \\
$\quad$ Middownward slope & $1.84^{\mathrm{a}}$ & $0.61^{\mathrm{a}}$ & $22.86^{\mathrm{a}}$ & $25.36^{\mathrm{b}}$ \\
$\quad$ Foot slope & $1.85^{\mathrm{a}}$ & $0.62^{\mathrm{a}}$ & $22.40^{\mathrm{a}}$ & $26.42^{\mathrm{b}}$ \\
Fertilizer & & & & \\
$\quad$ Non-fertilization & $1.40^{\mathrm{c}}$ & $0.46^{\mathrm{b}}$ & $17.28^{\mathrm{c}}$ & $25.04^{\mathrm{b}}$ \\
$\quad$ Chemical fertilization & $1.80^{\mathrm{b}}$ & $0.64^{\mathrm{a}}$ & $21.95^{\mathrm{b}}$ & $27.19^{\mathrm{a}}$ \\
$\quad$ Chemical+manure & $2.09^{\mathrm{a}}$ & $0.66^{\mathrm{a}}$ & $23.81^{\mathrm{a}}$ & $27.82^{\mathrm{a}}$ \\
Water & & & & \\
$\quad$ Without stress & $2.19^{\mathrm{a}}$ & $0.84^{\mathrm{a}}$ & $27.97^{\mathrm{a}}$ & $29.37^{\mathrm{a}}$ \\
$\quad$ Water stress & $1.33^{\mathrm{b}}$ & $0.33^{\mathrm{b}}$ & $14.05^{\mathrm{b}}$ & $24.00^{\mathrm{b}}$ \\
\hline
\end{tabular}

For each treatment, values with the same letters within columns are not significantly different by Tukey's test at $P \leq 0.05$. 

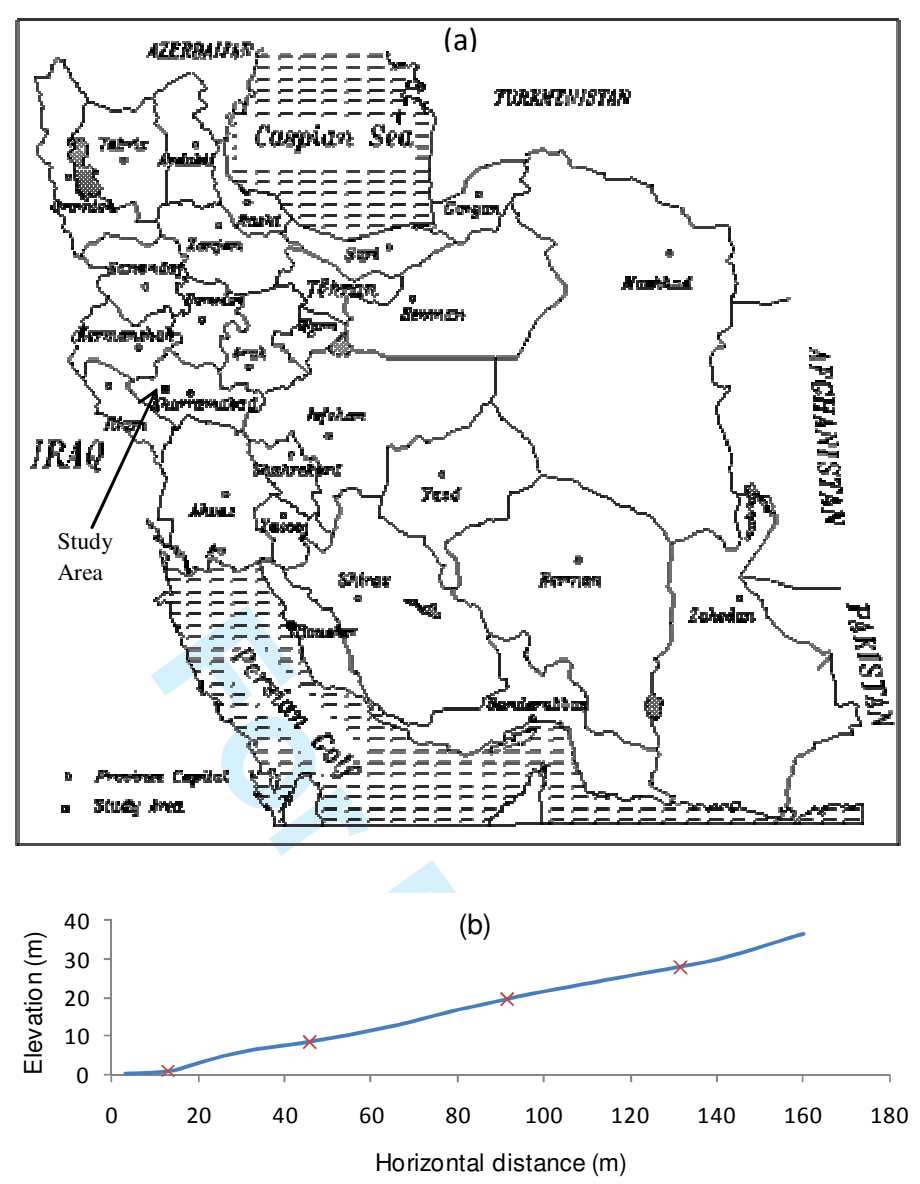

Figure 1. (a) Location of the study area within Iran, and (b) topographical variation of the study area. 

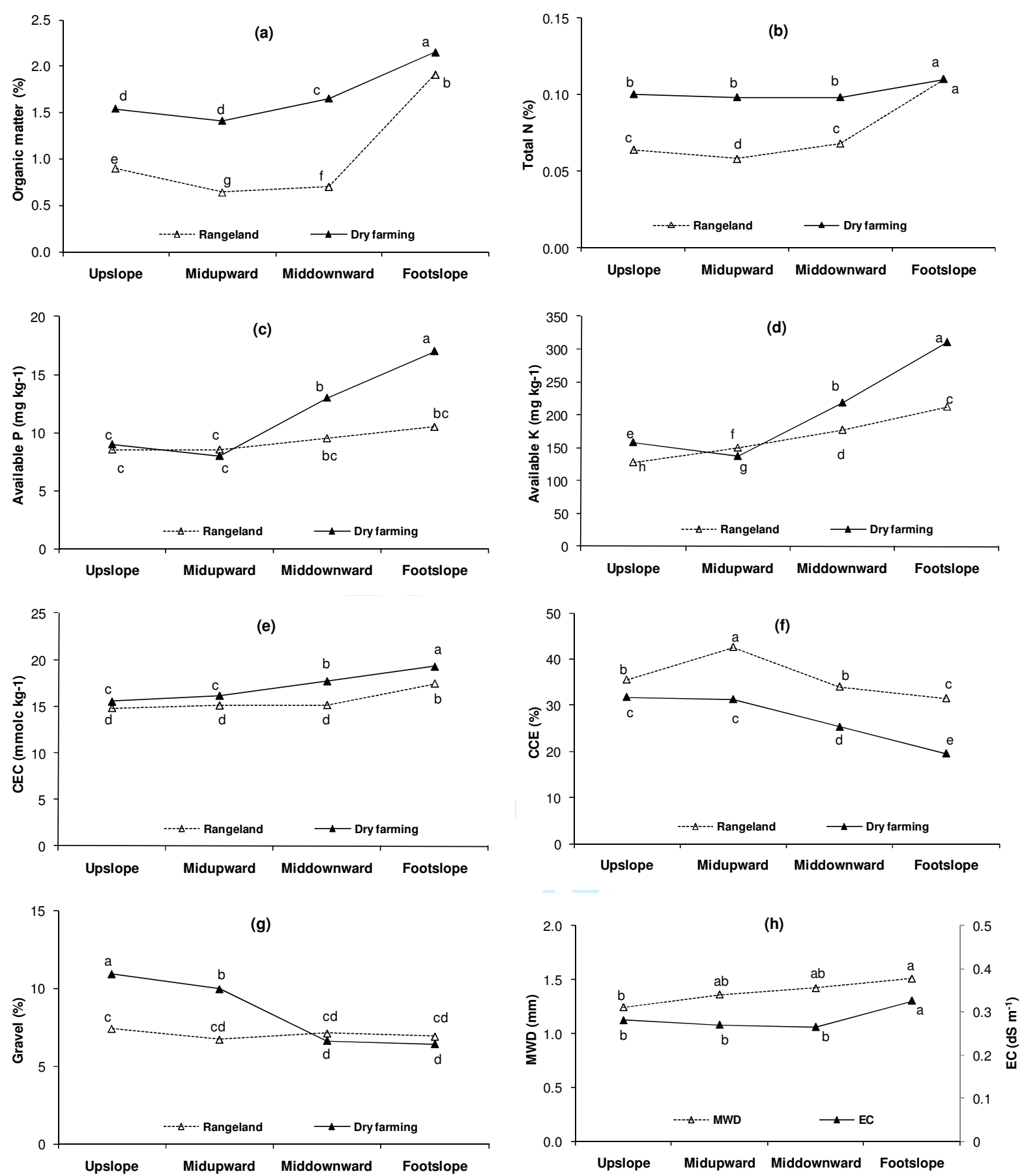

Figure 2. The mean comparison of land usexslope position interaction for (a) organic matter, (b) total nitrogen, (c) Available phosphorous, (d) available potassium, (e) cation exchange capacity, (f) calcium carbonate equivalent and $(\mathrm{g})$ rock fragment, and (h) mean comparison of slope position effect on mean weight diameter of soil aggregates and electrical conductivity.

Mean values with the same letters are not significantly different by Tukey's test at $P \leq 0.05$. 
(a)

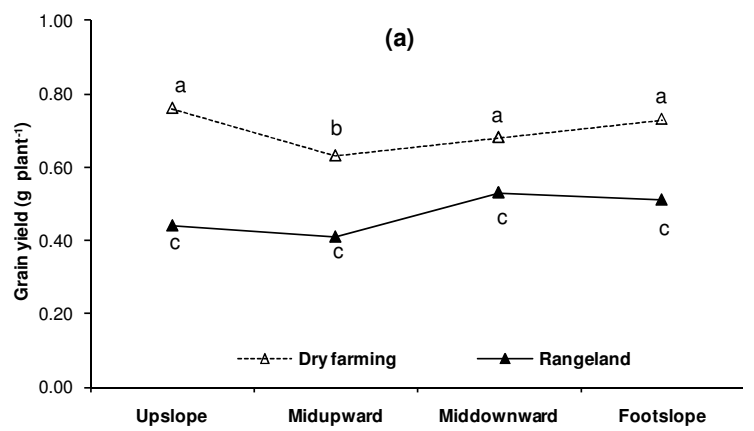

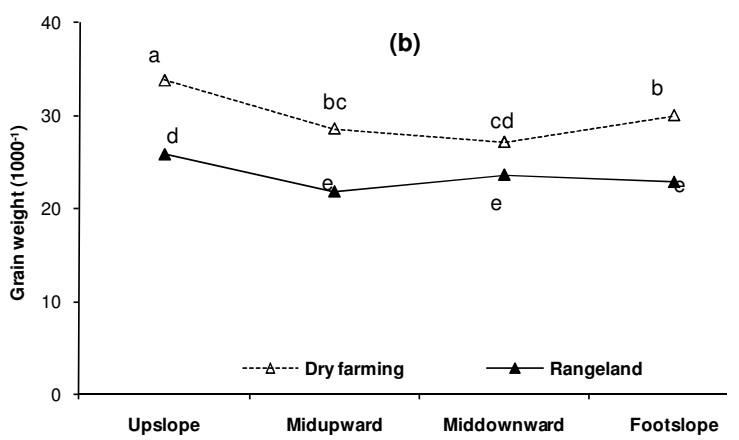

Figure 3. The mean comparison of land usexslope position interaction for wheat grain yield (a) and grain weight (b). Mean values with the same letters are not significantly different at $P \leq 0.05$. 

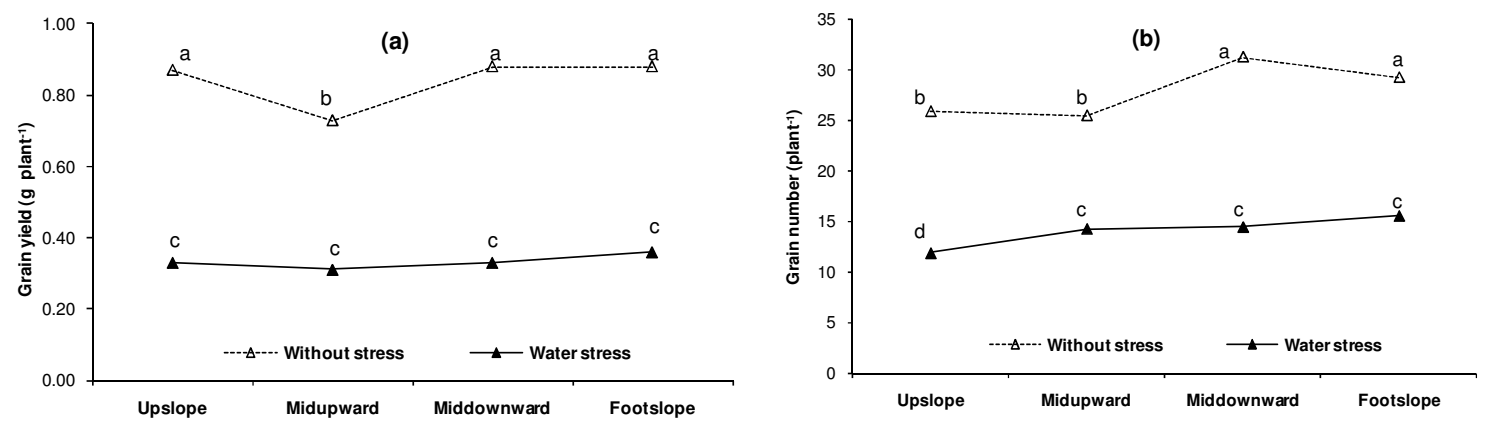

Figure 4. The mean comparison of slope position $\times$ water stress interaction for wheat grain yield (a) and grain number (b). Mean values with the same letters are not significantly different at $P \leq 0.05$. 

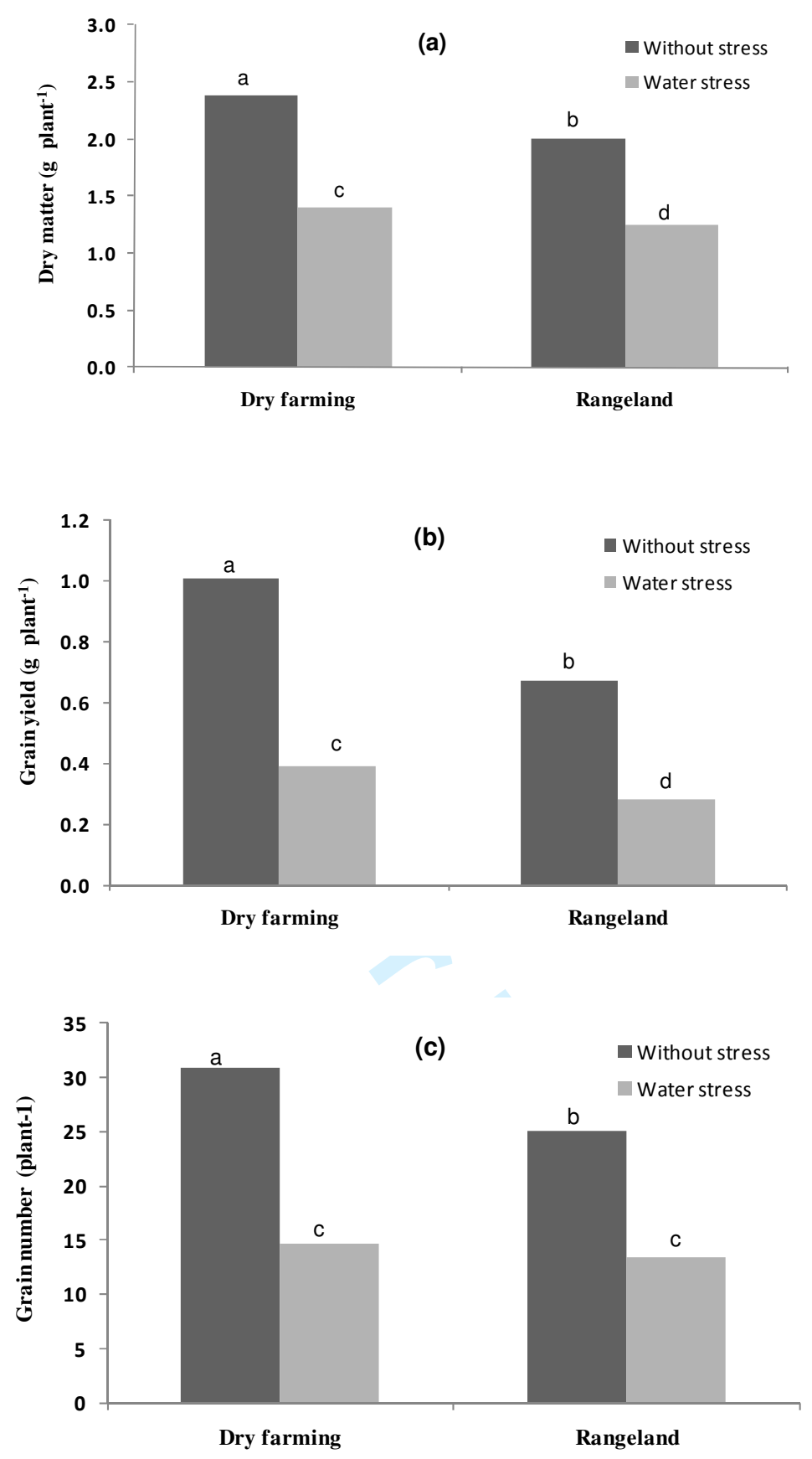

Figure 5. The mean comparison of land usexwater stress interaction for wheat dry matter (a), grain yield (b) and grain umber (c). Mean values with the same letters are not significantly different at $P \leq 0.05$. 

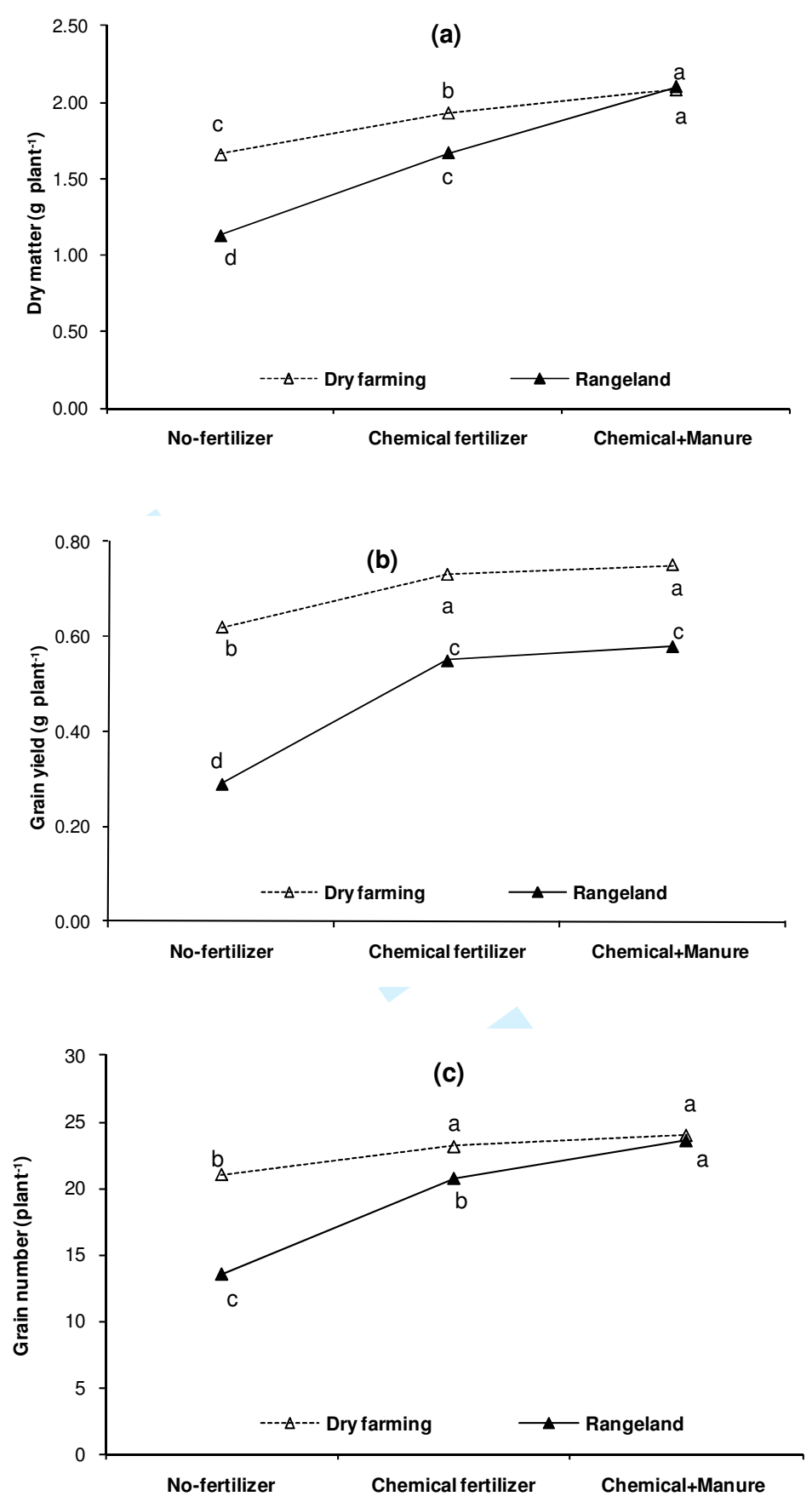

Figure 6. The mean comparison of land usexfertilizer interaction for wheat dry matter (a), grain yield (b) and grain number (c). Mean values with the same letters are not significantly different at $P \leq 0.05$. 

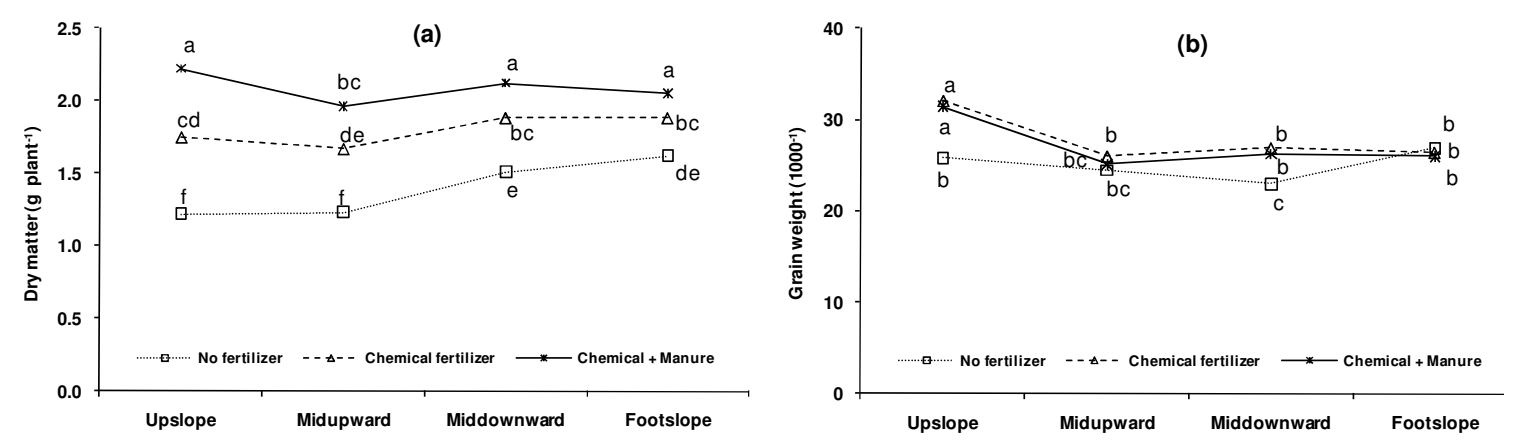

Figure 7. The mean comparison of slope position $\times$ fertilizer interaction for wheat dry matter (a) and grain weight (b). Mean values with the same letters are not significantly different at $P \leq 0.05$. 

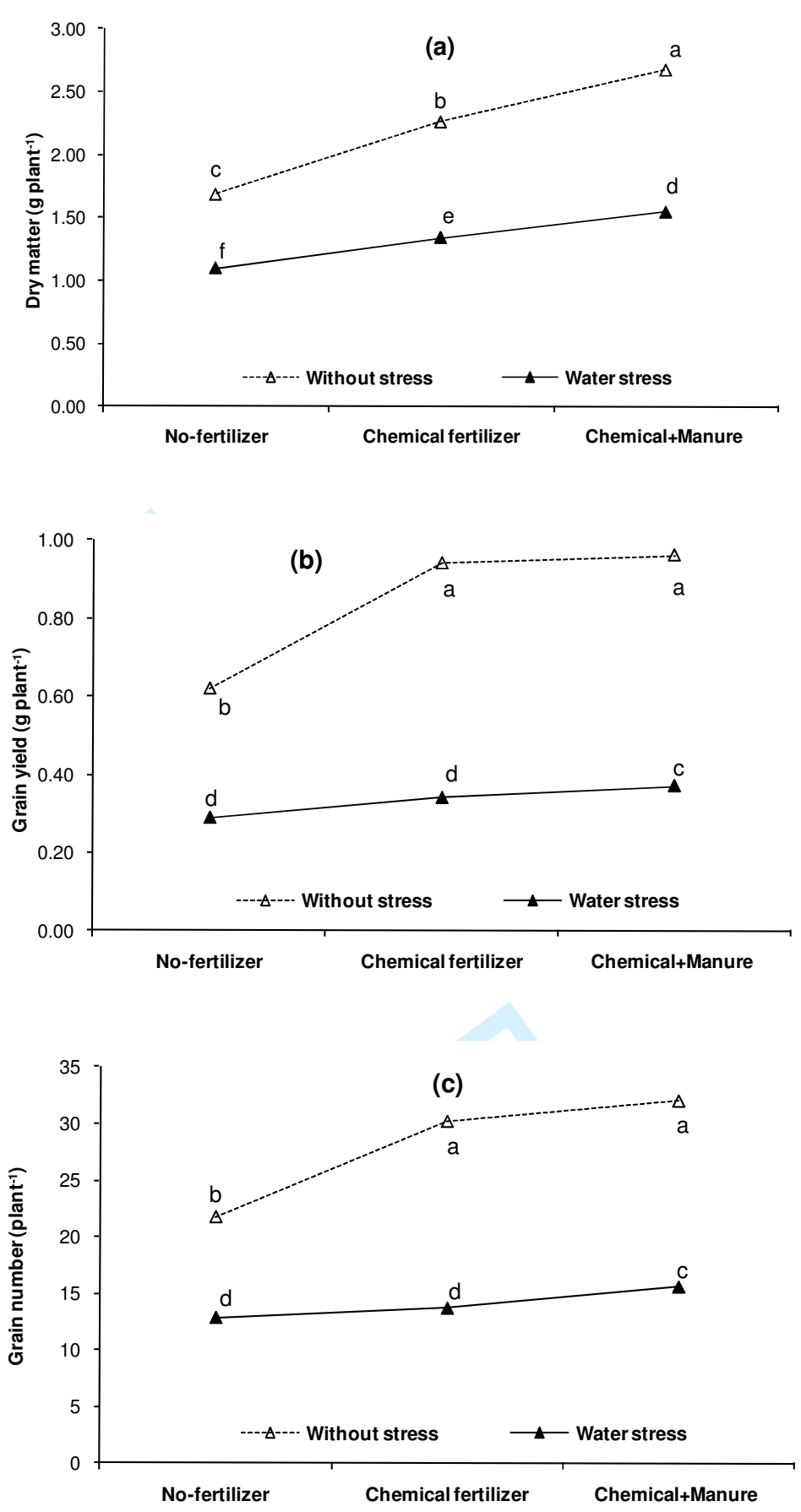

Figure 8. The mean comparison of fertilizer $x$ water stress interaction for wheat dry matter (a), grain yield (b) and grain number (c). Mean values with the same letters are not significantly different at $P \leq 0.05$ 